\section{PORCUPINE ALONG CUTARM CREEK}

by A. J. Hruska, Gerald

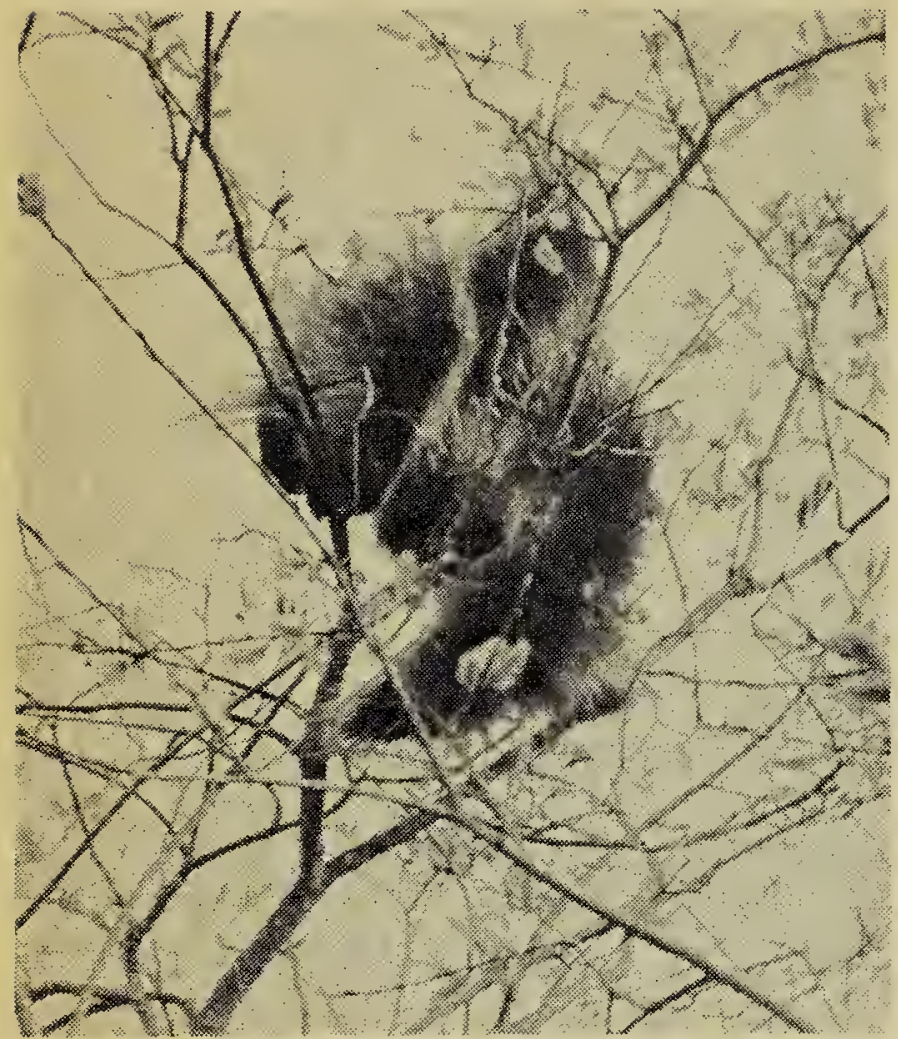

Our first observation of a Porcupine (Erethizon dorsatum) occurred in the late 1920's when I was attending public school. The caretaker of the school caged a large animal and his daughters invited the teacher and pupils to view this abominable creature that threw quills. We were duly warned to keep our distance. However, being slightly braver or more curious, I obtained a bunch of his quills. For many years I did not see a Porcupine or any damage caused by these rcbust rodents. They were quite rare $\mathrm{cr}$ at least not too abvious.

During the last ten years Porcupines have increased greatly along the Cutarm Creek and have spread out to the prairie. Perhaps one of the reasons for their increase is that they have no effective predator other than man. The damage that they do here by girdling willow and oak (so far I have not observed any damage to poplars). As a consequence I have destroyed every animal that has appeared on property that I designate as "out of bounds for porkies." The Porcupine illustrated was killed only 100 feet from the house-just too close to our evergreen hedge.

\section{IN DEFENCE OF THE WEASEL}

by E. Symons, Rocanville

Through the years I have gathered some really good stories proving the value of weasels. One of these comes from years ago when my father was sharpening pickets one summer afternoon and happened to notice a weasel loping up from a nearby slough, where there was an old straw pile, to the barn. A few minutes later it came back, carrying a rat. He saw that weasel make three more trips within about two hours, each time carrying a rat. Evidently the weasel was feeding a family of young. How many rats a day, and how many rats a season, would that weasel have killed?

Another illuminating weasel story was told me recently by a newfound friend, Henry Bauche, an old settler of the Antler district and a municipal councillor. Some years ago the Bauches had a weasel with a nest and young in the hen house! Never a chicken touched, but not a rat was seen around the farm yard. Significantly, during all the years (close to 25) that I lived on the farm, only once did a weasel molest poultry, and that weasel made a job of it-killed eleven hens and two ducks in one night. Yet there would be tracks all over the farm and around the hen house, all winter.

Jack Hass of McNutt, Sask., also told me recently of a neighbour whose chicken house is entered continually by a weasel. There are no rats left in the vicinity, but no chicken has ever been touched.

Earl Dixon at the elevator in Pinkie west of Regina told this story. A weasel came loping up the driveway, looked in the office, went and got a rat, then went out and around the engine house and buried the rat in the field. Dixon saw the weasel make 18 trips that afternoon, looking into the office every time!

Gordon Fisher of Regina tells of his sisters on the farm standing by the water trough when $a^{\circ}$ weasel passed by her chasing a rat. The weasel stopped for a drink, then went after his rat under the granary, and came by a few minutes later with a big one.

Surely these stories are an eloquent plea on behalf of the weasel. 